\title{
Implementasi Pendidikan Rabbani dalam Membentuk Karakter dan Kecerdasan Spiritual
}

\author{
Nasrulloh \\ Institut PTIQ Jakarta, Indonesia \\ Nasrullahmubarok2019@gmail.com
}

\begin{abstract}
Abstrak:
Tulisan ini bertujuan untuk menganalisis implementasi Pendidikan Robbani yang dilaksanakan di SDIT SUIS Bogor dalam membentuk karakter dan kecerdasan spiritual pada peserta didik. Jenis penelitian ini adalah kualitatif eskplanatif dengan pendekatan studi lapangan. Sumber data primer dan skunder dikumpulkan dengan metode indepth interview, FGD, observasi, dan studi dokumentasi. Teknik analisis data menggunakan teori Miles and Huberman dengan tahapan reduksi data, penyajian data, dan penarikan kesimpulan atau verifikasi. Keabsahan data diuji dengan menggunakan metode trianggulasi data untuk mendapatkan kualitas makna pada hasil wawancara. Temuan penelitian di antaranya adalah bahwa metode mendidik dengan keteladanan dan pembiasaan saja tidak cukup untuk memaksimalkan tingkat keberhasilan dalam pendidikan karakter dan kecerdasan spiritual. Penulis memandang bahwa pembentukan karakter dan kecerdasan spiritual akan lebih maksimal lagi jika menggunakan teori Nashil Ulwan secara menyeluruh yaitu mendidik dengan keteladanan, mendidik dengan pembiasaan, mendidik dengan nasihat, mendidik dengan perhatian, dan mendidik dengan hukuman.
\end{abstract}

Kata Kunci: Pendidikan Robbani, Peserta Didik, Pembentukan Karakter, Kecerdasan Spiritual.

\begin{abstract}
:
This paper aims to analyze the implementation of Robbani Education carried out at SDIT SUIS Bogor in shaping the character and spiritual intelligence of students. This type of research is descriptive qualitative with a field study approach. Primary and secondary data sources were collected using in-depth interviews, FGD, observation, and documentation studies. The data analysis technique uses the theory of Miles and Huberman with the stages of data reduction, data presentation, and drawing conclusions or verification. The validity of the data was tested by using the data triangulation method to get the quality of meaning in the interview results. The research findings include that the method of educating by example and habituation alone is not enough to maximize the level of success in character education and spiritual intelligence. The author views that the formation of character and spiritual intelligence will be maximized if using Nashil Ulwan's theory as a whole, namely educating by example, educating by habituation, educating with advice, educating with attention, and educating with punishment.
\end{abstract}

Keywords: Robbani Education, Students, Character Building, Spiritual Intelligence. 


\section{Pendahuluan}

Pendidikan rabbani sebagai pendidikan utama dan pertama dalam Islam. Al-Qur'an telah memberikan gambaran yang komprehensif tentang pendidikan Islam. Bahkan Al-Qur'an memberikan pedoman dalam mendidik anak mulai dari dalam kandungan sampai menyusui, kemudian ketika anak berusia tujuh tahun, sepuluh tahun dan seterusnya. Al-Qur'an juga mengaskan bahwa pendidikan anak merupakan tanggungjawab orang tua. Pendidikan AlQur'an sesungguhnya menuju pada pendidikan rabbaniyah, yaitu suatu konsep pendidikan yang dapat membentuk karakter peserta didik dengan sempurna dan menghasilkan kecerdasan spiritual. Pendidikan rabbaniyah menghasilkan generasi-generasi yang bertakwa, taat menjalankan perintah agama dan taat beribadah kepada Allah SWT.

Kata rabbaniyah diambil dari kata $r a b b$, dimana ia memiliki banyak makna, di antaranya pendidik atau pelindung. Jika kata ini berdiri sendiri, maka yang dimaksud tidak lain kecuali Allah. Bila dimaksudkan untuk menisbatkan atau mengkategorikan sesuatu, biasanya ditambahkan huruf ya di akhir, misalnya kata insan, jadi insaniy (bangsa manusia), atau kata rabb, jadi rabbaniyah (bersifat ketuhanan). Seseorang yang dikategorikan mempunyai sifat rabbaniyah, maka dia hendaklah bisa menjadi pencontoh Nabi Muhammad dan mengajak orang lain untuk mendekatkan diri kepada Allah. Dalam Al-Qur'an, mereka ini diidentikkan dengan ulama dan ahli fiqih. Sementara Ibnu 'Abbas menafsirkan kata rabbaniyah dengan ulama dan hukama, yakni orang yang berpengetahuan lagi berfilsafat. Dari sini, maka kata rabbaniyah dipahami sebagai orang yang mendedikasikan hidupnya untuk belajar dan mengajar secara istiqamah, sampai dia mengetahui rahasia mengapa diperintahkan. Sehingga, perasaannya bisa mendekati perasaan Allah. ${ }^{1}$

Pada hakikatnya, pendidikan rabbani tidaklah sama dengan pendidikan keagamaan dalam arti pendidikan kependetaan, seperti di Barat yang bernama religious education. Menurut Muhammad Sarbini, bahwa pendidikan semacam itu tidak ada di dalam kamus Islam, sebab pendidikan Islam mencakup Islam itu sendiri dengan segala konsepnya. ${ }^{2}$ Lebih lanjut, menurutnya konsep pendidikan rabbaniyah merupakan sesuatu yang amat penting dalam membentuk generasi yang kuat akidahnya, konsisten ibadahnya, dan baik akhlaknya, serta mampu bersaing dalam era globalisasi saat ini.

\footnotetext{
1 Hamka, Tafsir al-Azhhar Juz III, (Jakarta: Pustaka Panjimas, 1983), 217.

2 Muhammad Sarbini dan Unang Wahidin, "Pendidikan Rabbani untuk Penguatan Karakter Remaja". Edukasi Islami: Jurnal Pendidikan Islam, vol. 9, 1 Februari 2020, 151. 
Salah satu tujuan yang ingin dicapai dari konsep pendidikan rabbaniyah ini adalah terjadinya perubahan karakter peserta didik ke arah yang lebih baik dan memaksimalkan kecerdasan spiritual yang kurang diperhatikan oleh banyak konsep pendidikan ala Barat. Hal ini sejalan dengan apa yang disampaikan oleh Sidek Baba, bahwasanya pendidikan rabbaniyah bukan sekedar menyampaikan ilmu pengetahuan, keterampilan, dan latihan saja, akan tetapi ia mesti sejalan dengan prinsip dan nilai-nilai Al-Qur'an maupun hadis. ${ }^{3}$

Selain lembaga pendidikan pesantren yang sudah dikenal sejak lama di Indonesia, kini berkembang pula banyak sekolah Islam modern yang tidak memakai istilah pesantren, seperti Sekolah Dasar Islam (SDI), Sekolah Dasar Islam Terpadu (SDIT), hanya untuk menyebut nama Abu Bakar Islamic School, dan sebagainya. Kesemuanya sama-sama menekankan aspek keIslaman dalam seluruh proses pendidikan yang dijalankannya.

Berawal dari rasa keprihatinan yang mendalam atas rendahnya kualitas moral para generasi muda yang dilahirkan dari sistem pendidikan yang ada saat ini, dan diyakini bahwa penanaman nilai-nilai Islam yang murni secara sempurna harus dijadikan sebagai landasan utama dalam sistem pendidikan, maka pada tahun 2014 didirikanlah Sekolah Dasar Islam Terpadu, Sekolah Unggulan Islami (SDIT SUIS). Sekolah yang berada di bawah naungan Yayasan Islam Al-Huda Bogor Indonesia ini bertekad untuk dapat menghadirkan program pendidikan Islami unggulan yang diyakini mampu membentuk dan menghasilkan generasi Islami unggulan. ${ }^{4}$ Kurikulum yang diterapkan merupakan perpaduan antara kurikulum nasional dengan muatan lokal yang sarat dengan pengetahuan agama. Sehingga, menurut penulis, sekolah ini layak untuk dijadikan objek penelitian, bagaimana konsep pendidikan rabbaniyah diterapkan di sekolah tersebut.

Berdasarkan latar belakang penelitian maka dapat dirumuskan permasalahan sebagai berikut: (1) Bagaimana Konsep Pendidikan Rabbani Dalam Membentuk Karakter Peserta Didik di SDIT SUIS Bogor? (2) Bagaimana Konsep Pendidikan Rabbani Dalam Membentuk Kecerdasan Spiritual Peserta Didik di SDIT SUIS Bogor? (3) Bagaimana Analisa SWOT Pembentukan Karakter Dan Kecerdasan Spiritual Peserta Didik Melalui Pendidikan Al-Qur'an di SDIT SUIS Bogor?

${ }^{3}$ Sidek Baba, Pendidikan Rabbani: Mengenal Allah Melalui Ilmu Dunia, (Selangor: Karya Bestari Sdn. Bhd., 2006), 21.

${ }^{4}$ https://sekolahunggulanislami.com/selayang/. Diakses pada 12 Maret 2020. 
Nasrulloh

\section{Pengertian Rabbani}

Di dalam Al-Qur'an terdapat tiga ayat yang menyebutkan lafadz rabbani, yaitu surat Ali Imran ayat 79, Al Maidah ayat 44, dan Al Maidah ayat 63. Kata rabbani berakar dari kata يُرَبِّي yang memiliki beberapa makna di dalamnya. Di antaranya, mendidik, menjaga, merawat, dan membina. Pelaku yang melaksanakannya disebut dengan مُرَبِي yang berarti, yang merawat, mendidik, menjaga dan membina. Namun darimana asal kata رَبَّنَني tersebut. Dalam tafsir At Thabary karangan Abu Ja'far At-Thabary, Beliau menjelaskan darimana lafadz tersebut muncul. “Dikatakan darinya (yakni); pembina urusanku adalah si fulan, maka (yang dimaksud adalah) dia yang dibina olehnya adalah sebuah binaan, yakni pembina (raabbuhu). Maka apabilah diinginkan makna lebih dalam pujian kepadanya (yakni kepada pengurus tersebut), dikatakan bahwa (berubah menjadi) lafadz rabban, sebagaimana ada lafadz dia adalah sang tukang mengantuk (huwaa nu'saanun) dari kata na'sa-yan'usu.

Banyak juga lafadz yang datang dari nama-nama berdasarkan wazan fa'laanun. Ada yang merupakan fi'il madhi-nya merupakan wazan fa'ila. Seperti lafadz sukroonun, 'athsyaanun, dan rayyaanun yang merupakan dari fi'il sakiro-yaskiru, 'athisya-ya'thisyu, dan rawa-yarwa. Dan terdapat pula lafadz-lafadz yang merupakan wazan dari fa'la-yaf'ulu sebagaimana yang telah kami sebutkan dari lafadz na'asa-yan'usu dan rabba-yarubbu. Maka jika sebuah perkara yang terdapat pada hal tersebut yang mana telah kami sifati; yaitu lafadz ar-rabbaan yang telah kami sebutkan, sehingga lafadz ar-rabbaani merupakan sebuah lafadz yang dihubungkan (dinisbatkan) kepada apa yang telah disifati; yakni seorang yang memiliki pengetahuan akan ilmu fiqh dan hikmah dan merupakan termasuk dari golongan orang-orang yang salih, dia membina perkara umat, dengan pengajarannya mereka dalam sebuah kebaikan, serta mengajak mereka untuk menuju kepada sebuah ke-mashlahat-an; dan hal itu merupakan seorang hakim yang bertakwa kepada Allah SWT, dan seorang pemimpin yang membina semua urusan warganya atas jalan yang mana golongan orang-orang yang lurus dari orang-orang salih dengannya mereka membina urusan makhluk, dengan tegaknya hal tersebut pada mereka terhadap apa yang ada di dalamnya yakni kebaikan dunia dan akhirat mereka, dan menghasilkan sebuah kebermanfaatan di dunia maupun di akhirat; mereka itulah semua yang hendak menjadi golongan dari apa yang telah ada pada firman Allah SWT yaitu wa laakin kunuu arrabbaaniyiina (akan tetapi hendaklah kamu menjadi seorang rabbaani).

Pada lafadz ar-rabbaniyyuna maka dia merupakan sandaran bagi umat dalam urusan fiqh, ilmu, maupun perkara agama dan dunia. Dan karena demikian berkata Mujahid :'Dan mereka lebih daro seorang ahbar. Dikarenakan ahbar merupakan ulama saja, sedangkan arrabaani merupakan terkumpul di dalam dirinya ilmu dan fiqh, dan dia yang memiliki 174 | IQ (Ilmu Al-qur'an): Jurnal Pendidikan Islam| Volume 4 No. 022021 
pandangan terhadap politik dan pengaturan (negara), dan menegakkan urusan-urusan rakyat, dan mengajak rakyatnya kepada ke-mashlat-an baik di dunia maupun di akhirat."

Dalam penjelasan tersebut dipahami bahwa lafadz rabbani merupakan sebuah lafadz yang terbentuk atas rasa pujian yang amat mendalam kepada mereka yang selain memiliki ilmu, namun mereka pun menegakkan hak-hak umat, mengajak kepada kesalihan, tidak hanya di dunia, akan tetapi sampai akhirat. Penjelasan tersebut kembali diulang oleh seorang ulama, yakni Imam Syibawaih. Beliau berkata :

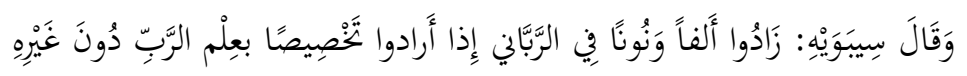

Berkata Imam Syibawaih :'Kamu sekalian menambahkan alif dan nun pada lafadz arrabbaani (yakni) jika kalian menginginkan sebuah (makna) pengkhususan terhadap pengetahuan pada rabb (dan) bukan selainnya"6

Pada keterangan di atas dipahami bahwa makna dibalik pengetahuan pada rabb, merupakan sebuah penghayatan akan sifat Allah yang Maha Mengurus. Sehingga, manusia terdorong dan termotivasi dengan penghayatan tersebut. Output dari penghayatan itu menghasilkan konsep pembelajaran dengan mengacu kepada bagaimana Maha Sayang Allah kepada hamba-Nya, Maha Pengasih dalam mendidik hamba-Nya.

\section{Konsep Pendidikan Rabbaani}

Mengacu kepada dasar dari asal kata rabbaani yang terdapat di dalam Al-Qur'an, maka melalui tafsir dari ayat tersebut dapat ditemukan konsep-konsep pendidikan rabbaani secara garis besar yang mencakup dasar dan tujuan pendidikan rabbani, di antaranya adalah sebagai berikut:

1) Mencerdaskan peserta didik, termasuk di dalamnya meningkatkan dan mengembangkan kecerdasan peserta didik.

2) Membangun budi pekerti yang luhur. Akhlak atau budi pekerti yang luhur, membangun manusia menjadi makhluk yang sempurna. Hal ini selaras dengan penyampain Nabi Muhammad SAW;

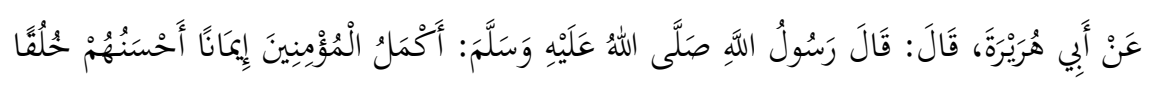

"Diriwayatkan dari Abu Hurairah RA, Rasulullah SAW pernah bersabda; 'Kemuliaan orang yang beriman adalah kesempurnaan akhlaknya"7

\footnotetext{
${ }^{5}$ Abu Ja'far Ath-Thabary, Tafsir Ath-Thabary, ( Mesir : Muassasah Ar-Risalah 2000M), Jld.6, 543..

${ }^{6}$ Muhammad bin Mukrim Al Ifriqy, Lisaan Al Araby, (Beirut : Daaru Shodir 1414 H), 403.

${ }^{7}$ Abu Dawud Sulaiman as-Sijistaan, Sunan Abi Dawud, (Beirut : Al-Maktabah al-'ishriyyah), Jld.4, 220.
} 
3) Implementasi Pendidikan Rabbani

Dalam penelitian ini konteks penggunaan kata implementasi adalah pada implementasi pembelajaran yang dilaksankan di SDIT SUIS Bogor.

a) Perencanaan Pembelajaran

Menurut Roger A. Kaufman ${ }^{8}$ yang dimaksud dengan perencanaan adalah perkiraan tentang apa yang diperlukan dalam rangka mencapai tujuan absah dan bernilai. Sedangkan menurut Nadzir perencanaan adalah serangkaian kegiatan yang dilakukan di masa depan ${ }^{9}$. Pola pikir dalam perencanaan meliputi perencanaan yang melibatkan proses penetapan keadaan masa depan, kemudian membandingkan keadaan masa depan dengan kondisi sekarang, dan untuk menutup gap atau kesenjangan antara kondisi saat ini dengan kondisi yang diharapkan pada masa depan maka perlu dilakukan usaha-usaha yang efektif dan maksimal.

b) Tujuan dan Fungsi Perencanaan Pembelajaran

Tujuan pembelajaran yang efektif harus dilakukan untuk meningkatkan prestasi peserta didik. ${ }^{10}$ Adapun fungsi perencanaan pembelajaran adalah memberikan guru pemahaman yang lebih jelas tentang tujuan pendidikan sekolah dan hubungannya dengan pembelajaran yang dilaksanakan untuk mencapai tujuan tersebut. Kemudian membantu guru untuk memperjelas pemikiran tentang kontribusi pembelajarannya terhadap pencapaian tujuan pendidikan.

c) Proses Pembelajaran

Proses pembelajaran pada satuan pendidikan harus diselenggarakan secara interaktif, inspiratif, menyenangkan, menantang, memotivasi peserta didik untuk berpartisipasi aktif, serta memberikan ruang yang cukup bagi prakarsa, kreatifitas dan kemandirian sesuai dengan bakat, minat, dan perkembangan fisik serta psikologis peserta didik. Proses pembelajaran merupakan kegiatan yangdilakukan guru mulai dari perencanaan, pelaksanaan kegiatan sampai evaluasi dan program

8 Umar Mansyur, "Perencanaan Pembelajaran Bahasa Indonesia”, Artikel Ilmiah, file://C:/Users/ASUS/AppData/Local/Temp/PERENCANAAN_PEMBELAJARAN_BAHASA_INDONESI.pd f diakses pada tanggal 16 Oktober 2020.

${ }_{9}^{9}$ M. Nadzir, "Perencanaan Pembelajaran Berbasis Karakter", Jurnal Pendidikan Agama Islam, (2013), Vol. 02, No. 02. 339-352.

${ }^{10}$ Fakhrurrazi, "Hakikat Pembelajaran yang efektif”, Jurnal At-Tafkir, (2018), Vol. 11, No. 01, 87.

176 | IQ (Ilmu Al-qur'an): Jurnal Pendidikan Islam| Volume 4 No. 022021 
tindak lanjut yang berlangsung dalam situasi edukatif untuk mencapaitujuan tertentu. $^{11}$

d) Evaluasi Pembelajaran

Evaluasi merupakan langkah-langkah terstruktur untuk memutuskan maksud dan tujuan suatu nilai dalam sebuah pembelajaran, kinerja, kegiatan, proses, dan sebagainya berdasarkan parameter tertentu. Evaluasi yang baikharuslah didasarkan atas tujuan yang ditetapkan berdasarkan perencanaan sebelumnya dan kemudian benar-benar diusahakan oleh guru untuk peserta didik. ${ }^{12}$

\section{Metode Penelitian}

Jenis penelitian ini adalah kualitatif eksploratif. ${ }^{13}$ Penelitian kualitatif eksploratif bertujuan untuk menggali data lebih dalam terkait dengan objek penelitian, penelitian ini berusaha menghubungkan antara satu data dengan data yang lainnya untuk melihat kompleksitas permasalahan sehingga penulis mendapatkan gambaran yang utuh tentang permasalahan yang sedang dikaji. ${ }^{14}$ Jenis penelitian kualitatif eksploratif melihat kedalaman permasalahan untuk mengeksplorasi berbagai kemungkinan yang timbul dari masing-masing variabel yang dianalisis, sehingga dengan demikian substansi masalah mudah dikuasai dan dianalisis. ${ }^{15}$ Desain $^{16}$ penelitian kualitatif eksploratif biasanya dilakukan apabila didapati sedikit sekali kajian penelitian yang membahas satu hal tertentu. Fokus model ini adalah memperoleh wawasan ketika peneliti mulai melakukan penyelidikan pada awan permulaan penelitian.

${ }^{11}$ Siti Aini Latifah A, "Proses Pembelajaran Pendidikan Agama Islam di SMP Plus Assalam Bandung", Jurnal Tarbawi, (2012), Vol. 01, No. 01, 13.

12 Tatang Hidayat dan Abas Asyafah, "Konsep Dasar Evaluasi dan Implikasinya Dalam Evaluasi Pembelajaran Agama Islam di Sekolah", At-Tadzkiyah: Jurnal Pendidikan Agama Islam, (2019), Vol. 10, No. 01. 163.

${ }^{13}$ Penelitan kualitatif eksploratif bertujuan untuk memberikan kepuasan bagi peneliti untuk memahami persalahan secara lebih mendalam. Sandu Siyoto, Dasar Metodologi Penelitian, (Yogyakarta: Literasi Media Publishing, 2015), 8 .

14 Kotler mengatakan bahwa penelitian kualitatif dengan pendekatan eksploratif bertujuan untuk mengetahui dan memahami objek penelitian yang belum diketahui dan dipahami oleh banyak orang. Penelitian ini bersifat menarik perhatian. Dovel Pirmanto, Muhammad Labib Jundillah, Krisan Aprian Widagdo, "Jenis Penelitian Menurut Kedalaman Analisis Data" Artikel Ilmiah, file://C:/Users/ASUS/AppData/Local/Temp/Penelitian Deskriptif Ekploratori dan Ek.pdf, diunduh pada tanggal 12 Oktober 2020.

${ }^{15}$ Menurut Kultar Shing bahwa penelitian kualitatif eksploratif memerlukan penjajakan dan penjelahan yang cukup untuk memahami gejala sosial yang timbul. Bambang Mudjiyanto, "Tipe Penelitian Eksploratif Komunikasi”, Jurnal Studi Komunikasi dan Media, Vol. 22, No. 01 (2018), 66.

${ }^{16}$ Bagi paradigma ilmiah, desain harus disusun secara pasti sebelum fakta dikumpulkan. Sekali desain penelitian digunakan maka tidak boleh mengubahnya dalam bentuk apapun. Dewi Sadiah, Metode Penelitian Dakwah, Pendekatan Kualitatif dan Kuantitatif, (Bandung: Remaja Rosdakarya, 2015), 28. 
Desain eksplorasi juga sering digunakan untuk membangun pemahaman yang mendalam dan komprehensif dalam rangka menentukan metodologi yang tepat. ${ }^{17}$

Dalam penelitian ini penulis menggunakan pendekatan studi kasus. ${ }^{18}$ Penelitian lapangan atau yang sering disebut dengan field study tertarik untuk memahami objek penelitian secara langsung. ${ }^{19}$ Kondisi di lapangan yang terjadi dapat memberikan gambaran yang komprehensif. ${ }^{20}$ Yang dapat dijadikan subjek dalam penelitian lapangan bisa individu, masyarakat atau institusi. ${ }^{21}$ Dalam penelitian lapangan posisi peneliti harus terlibat langsung dengan objek penelitian ${ }^{22}$ atau melekat langsung dengan objek penelitian sehingga peneliti dapat menghayati dan merasakan fenomena yang terjadi di lapangan, hal tersebut menjadikan peneliti memiliki gambaran yang utuh dan mendalam terhadap objek kajian. ${ }^{23}$ Studi kasus instrumental berusaha memahami objek tertentu yang dirumuskan kembali dan dipahami secara teoritis. ${ }^{24}$

Karakteristik pada penelitian kualitatif pada umumnya adalah mencari dan menemukan esensi dari pengalaman manusia, dalam hal ini misalkan pengalaman seorang kepala sekolah, guru, dan lain sebagainya, kemudian menggali faktor-faktor kualitatif, dan memberikan penjelasan yang komprehensif, hidup, dan akurat dengan menampilkan data-data yang valid dan terkonfirmasi. ${ }^{25}$

Rentang waktu penelitian ini dilaksanakan mulai dari bulan Juli 2019 sampai dengan bulan September 2020. Objek penelitian adalah SDIT SUIS yang beralamat di Kampung Cimanglid, RT. 03, RW. 01, Desa Sukamantri, Kecamatan Tamansari, Kabupaten Bogor. ${ }^{26}$

\section{7.}

${ }^{17}$ Ismail Nurdin, Sri Hartati, Metodologi Penelitian Sosial, (Surabaya: Media Sahabat Cendekia, 2019),

18 Suyitno, Metode Penelitian Kualitatif, Konsep, Prinsip, dan Operasionalnya, (Tulung Agung: Akademi Pustaka, 2018), 90. 2015), 29

19 Sandu Siyoto, Ali Sodik, Dasar Metodologi Penelitian, (Yogyakarta: Literasi Media Publishing,

${ }^{20}$ Alan Bryman, Social Research Method, Writing Up Social Research, 55.

21 Suyitno, Metode Penelitian Kualitatif, Konsep, Prinsip, dan Operasionalnya, (Tulung Agung: Akademi Pustaka, 2018), 90.

${ }^{22}$ Peneliti studi kasus berupaya menelaah sebanyak mungkin data mengenai subjek yang diteliti. Deddy Mulyana, Metodologi Penelitian Kualitatif, Paradigma Baru Ilmu Komunikasi dan Ilmu Sosial Lainnya Dilengkapi dengan Contoh-Contoh Penelitian, (Bandung: Remaja Rosdakarya, 2018), 247. 2019), 80.

${ }^{23}$ Ismail Nurdin dan Sri Hartati, Metodologi Penelitian Sosial, (Surabaya: Penerbit Media Cendekia, 2019),

81.

${ }^{24}$ Ismail Nurdin dan Sri Hartati, Metodologi Penelitian Sosial, (Surabaya: Penerbit Media Cendekia,

${ }^{25}$ Engkus Kuswarno, Metodologi Penelitian Komunikasi, Fenomenologi: Konsep, Pedoman, dan Contoh Penelitian, (Bandung: Widya Padjajaran, 2009), 59.

26 https://sekolahunggulanislami.com/ppdb-sdit-suis-tp-20172018/, Profil SDIT SUIS, diakses pada tanggal 12 Oktober 2020.

178 | IQ (Ilmu Al-qur'an): Jurnal Pendidikan Islam| Volume 4 No. 022021 
Sumber data $\operatorname{primer}^{27}$ berupa hasil wawancara mendalam secara terstruktur dengan beberapa informan mulai dari Kepala Sekolah, Wakil Kepala Sekolah Bidang Kurikulum, Wali Kelas, Guru-Guru PAI, Peserta Didik, Orangtua Siswa, Masyarakat, Tokoh Masyarakat, dan Tokoh Pendidikan setempat. Data primer juga bersumber dari hasil kegiatan focus group discussion dan observasi yang dilakukan secara langsung oleh penulis secara partisipan. Sumber data sekunder ${ }^{28}$ berupa hasil dari studi dokumentasi berupa profil sekolah, kurikulum, metode pembelajaran yang diterapkan, program in house training untuk peningkatan kompetensi guru, model evaluasi pembelajaran, dan lain-lain. Data skunder juga bersumber dari berbagai sumber referensi, informasi, dan bahan kajian yang relevan, seperti buku, jurnal nasional dan internasional bereputasi, kurikulum 2013 dan lain-lain.

Indepth Interview merupakan teknik pengambilan data dengan melakukan komunikasi dengan informan baik secara terstruktur, semi terstruktur, maupun tidak terstruktur. ${ }^{29}$ Dalam penelitian ini penulis menggunakan teknik wawancara mendalam secara terstruktur. Observasi merupakan catatan lapangan yang diperoleh dari hasil pengamatan dan dituangkan dalam transkip. ${ }^{30}$ Selama penelitian berlangsung posisi peneliti sebagai human instrument maka harus meluangkan waktu sebanyak-banyaknya untuk bergabung dan terlibat di lapangan guna memperoleh beragam informasi yang bersumber dari fenomena yang diamati secara natural. ${ }^{31}$ Studi dokumentasi merupakan teknik pengumpulan data dengan cara mempelajari data-data yang diperlukan dalam penelitian sesuai tema penelitian. ${ }^{32}$ FGD atau diskusi kelompok ${ }^{33}$ merupakan alat penting yang digunakan untuk mengeksplorasi bagaimana sudut pandang

${ }^{27}$ Data primer adalah data yang didapatkan dari sumber pertama atau sumber asli. Nuning Indah Pratiwi, "Penggunaan Media Video Call Dalam Teknologi Komunikasi”, Jurnal Ilmiah Dinamika Sosial (2017), Vol. 01, No. 02, 211.

${ }^{28}$ Data sekunder adalah data yang telah disediakan oleh pihak lain, atau data yang diperoleh dari tangan kedua, ketiga dan seterusnya. https://insanpelajar.com/data-sekunder/, Data Sekunder: Pengertian, Ciri-Ciri, dan Contohnya, Diakses pada tanggal 13 Oktober 2020.

${ }^{29}$ Penggunaan indepth interview sangat signifikan dalam memahami secara mendalam tentang persepsi masing-masing individu terhadap suatu fenomena yang sedang diteliti. Agustinus Bandur, Penelitian Kualitatif, Metodologi, Desain, dan Teknik Analisis Data dengan NVIVO 11 Plus, (Jakarta: Mitra Wacana, 2016), 108.

30 Teknik pengumpulan data kualitatif melalui observasi langsung sangat relevan untuk mendapatkan pola perilaku dan peristiwa yang dibutuhkan untuk mendalami masalah penelitian. Agustinus Bandur, Penelitian Kualitatif, Metodologi, Desain, dan Teknik Analisis Data dengan NVIVO 11 Plus, (Jakarta: Mitra Wacana, 2016), 105.

${ }^{31}$ http://lppm.univetbantara.ac.id/data/materi/Buku.pdf, Farida Nugrahani, Metode Penlitian Kualitatif Dalam Penelitian Pendidikan Bahasa, 62.

${ }^{32}$ Studi dokumentasi dilakukan untuk mencari data yang terkait dengan variabel berupa catatan, trankrip, buku, bahan bacaan, dan lain-lain. Sandu Siyoto, Ali Sodik, Dasar Metodologi Penelitian, (Yogyakarta: Literasi Media Publishing, 2015), 78.

33 FGD sangat populer digunakan sejak dekade 1990an (Krahn \& Putnam, 2003), dalam teknik ini peneliti dapat menggabungkan beberapa partisipan dalam satu kelompok diskusi. Agustinus Bandur, Penelitian Kualitatif, Metodologi, Desain, dan Teknik Analisis Data dengan NVIVO 11 Plus, (Jakarta: Mitra Wacana, 2016), 108-109. 
terbentuk untuk diekspresikan. Dalam FGD partisipan diberikan kebebasan berbicara dengan partisipan lainnya.

Miles dan Huberman berpandangan bahwa analisis adalah kegiatan pengurutan data, pengorganisasian data, interpretasi data, dan penilaian data. Mereduksi data adalah untuk menyederhanakan data yang diperoleh di lapangan baik dengan cara wawancara, observasi, studi dokumentasi maupun dengan FGD. Kemudian menyajikan data sesuai dengan pokok permasalahan yang diawali dengan kegiatan pengkodean pada setiap sub pokok penelitian.

Dalam Melakukan penarikan kesimpulan urgensi adalah menemukan makna dari data-data yang telah dikumpulkan dengan mencari hubungan, persamaan, dan perbedaan pada masingmasing data tersebut. Verifikasi dapat berupa peninjauan kembali pada catatan lapangan yang mungkin berlangsung sekilas atau dilakukan dengan seksama yang membutuhkan waktu yang cukup. Makna-makna yang muncul dari data harus diuji kebenarannya, kekokohannya, dan kecocokannya sehingga validitasnya terbentuk. ${ }^{34}$

\section{Hasil Penelitian dan Pembahasan}

Berdasarkan data primer dan skunder yang didapat dari hasil wawancara, observasi, studi dokumentasi, dan focus group discussion bahwa implementasi pendidikan Al-Qur'an yang diterapkan di SDIT SUIS dilakukan dengan metode mengkombinasi mata pelajaran Pendidikan Islam dan Budi Pekerti dengan beberapa mata pelajaran muatan lokal yang merupakan mata pelajaran unggulan. Pelaksanaan pembelajaran dilakukan di dalam kelas dan di luar kelas. Mata pelajaran seperti PAI dan Budi Pekerti dilaksanakan di dalam kelas, sedangkan Fikih, Akidah, Bahasa Arab, dan Al-Qur'an dilaksanakan di luar kelas.

\section{Perencanaan Pembelajaran Dalam Membentuk Karakter dan Kecerdasan Emosional Peserta Didik di SDIT SUIS Bogor}

Menurut Nashih Ulwan target pendidikan untuk jenjang usia anak pada fase awal adalah keimanan. ${ }^{35}$ Media yang paling tepat digunakan yaitu dengan pembelajaran Al-

\footnotetext{
${ }^{34}$ Engkus Kuswarno, Metodologi Penelitian Komunikasi, Fenomenologi: Konsep, Pedoman, dan Contoh Penelitian, (Bandung: Widya Padjajaran, 2009), 137.

35 Abdullah Nashih Ulwan, Pendidikan Anak Dalam Islam Yang Komprehensif, (Bandung: Dilariza, 2019), hal 1.

180 | IQ (Ilmu Al-qur'an): Jurnal Pendidikan Islam| Volume 4 No. 022021
} 
Qur'an. ${ }^{36}$ Hal tersebut seperti dijelaskan dalam Al-Qur'an Surat Al-Anfal ayat 2, Allah berfirman,

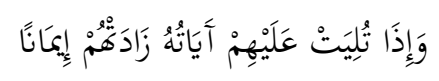

"Apabila dibacakan kepada mereka ayat-ayat-Nya maka bertambahlah keimanan mereka." (QS. Al-Anfal: 2). Metode ini pula yang dijalankan oleh Rasulullah SAW dalam mendidik para sahabatnya. Allah berfirman,

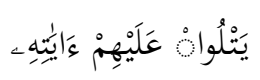

“Membacakan ayat-ayat-Nya kepada mereka." (QS. Al-Jumu'ah: 2). Pada tahun pertama hijriah sampai dengan tahun ke tigabelas Hijriah ayat-ayat Al-Qur'an yang pertama kali turun lebih banyak membicarakan tentang keimanan. Hal tersebut membuktikan bahwa fokus pendidikan pada fase awal adalah fokus pada membangun fondasi keimanan. Fondasi iman yang kokoh dan kuat pada anak lebih mudah untuk ditanamkan nilai-nilai akhlakul karimah. Konsep ini yang kemudian diyakini oleh SDIT SUIS Bogor dalam membentuk karakter dan kecerdasan spiritual peserta didik melalui program pendidikan Ke-Islaman berbasis Al-Qur'an. Ide besar ini kemudian dituangkan dalam perencanaan pembelajaran yang terkonseptualisasi dalam RPP, Kurikulum, Silabus, dan lain sebagainya. ${ }^{37}$ Perencanaan pembelajaran berbasis AlQur'an untuk usia anak sekolah dasar disesuikan dengan tingkatan jenjang tersebut. Khusus untuk kompetensi mata pelajaran Al-Qur'an diberikan porsi paling besar dibandingkan dengan mata pelajaran yang lain. SDIT SUIS memandang bahwa pada usia golden age peserta didik harus betul-betul sudah akrab dengan Al-Qur'an. ${ }^{38}$

Peserta didik wajib menghafalkan satu juz minimal setiap tahun. Target tersebut terbilang ringan jika dibandingkan dengan sekolah-sekolah model tahfidz lainnya, tetapi yang menjadi keunggulan pembelajaran Al-Qur'an di SDIT SUIS adalah bahwa anak-anak terlebih dahulu harus menguasai ilmu tajdwid, tahsin, dan lancar dalam membaca Al-Qur'an. Kompetensi membaca Al-Qur'an dengan lancar dan sesuai dengan makhrojul huruf yang benar akan memudahkan peserta didik dalam menghafalkan Al-Qur'an ke depannya.

Konsep menghafal Al-Qur'an di sekolah full day seperti ini memang dirasa kurang efektif, sebab ketika peserta didik di rumah ia harus menghafal Al-Qur'an secara mandiri. untuk itu SDIT SUIS melibatkan orang tua dalam mengawal peserta didik menghafal Al-

${ }^{36}$ Izan, Ahmad, Saehudin, Tafsir Pendidikan: Konsep Pendidikan Berbasis Al-Qur'an, (Yogyakarta: Perpustakaan Magister Studi Islam UII, 2015), hal 38.

${ }^{37}$ Hasil Wawancara dengan Wakil Kepala Sekolah SDIT SUIS Bogor, pada tanggal 20 Oktober 2020.

${ }^{38}$ Hasil Wawancara dengan Kepala Sekolah SDIT SUIS Bogor, pada tanggal 20 Oktober 2020. 
Qur'an di rumah. Dalam konsep pembelajaran ini penulis mengkritik bahwa porsi waktu khusus menghafal Al-Qur'an di sekolah perlu ditambah atau diberikan waktu satu hari penuh dalam satu pekan khusus untuk menghafal Al-Qur'an.

Untuk perencanaan pembelajaran mata pelajaran diniyah sudah memenuhi standar kurikulum 2013. Berdasarkan hasil wawancara dengan Wakil Kepala Sekolah Bidang Kurikulum $^{39}$ dan hasil studi dokumentasi SDIT SUIS telah memiliki perencanaan yang tepat dan efektif. Seluruh dokumen pembelajaran terdata dengan lengkap. Pimpinan SDIT SUIS memiliki komitmen yang kuat dalam membangun budaya kerja yang teratur, disiplin, dan rapih, maka wajar jika SDIT SUIS memperoleh nilai akrediatsi A pada tahun 2018, menempati Juara 1 lomba tahfidz tingkat kecamatan dan kabupaten, dan juara 2 LCC PAI tingkat kecamatan. ${ }^{40}$

Perencanaan program keteladanan dan pembiasaan juga terdokumentasikan dengan baik. Program keteladanan dan pembiasaan tidak termasuk dalam mata pelajaran apapun, namun kedua program ini memiliki posisi yang sangat strategis dalam upaya mencapai target pembelajaran. Program keteladanan dan pembiasaan berusaha melakukan negosiasi yang kuat dalam pembentukan karakter dan perubahan perilaku pada peserta didik, baik itu sikap spiritual maupun sikap sosial yang menjadi topik inti dalam pembahasan ini.

Program ini menawarkan contoh sikap dan perilaku yang dilakukan oleh guru secara spontan dan konsisten. Pada fase anak usia SD sikap yang bersifat demonstratif lebih mudah diduplikasi, karena pada usia tersebut peserta didik banyak menggunakan indera penglihatan ketimbang indera pendengaran. Anak lebih senang menonton daripada mendengar. Segala sesuatu yang dilihat oleh anak lebih mudah ditiru, oleh karena itu guru dan orang tua harus berusaha semaksimal mungkin untuk memberikan contoh yang baik di depan peserta didik.

Keteladanan dan pembiasaan yang dilakukan secara konsisten dan terus-menerus terbukti efektif merubah perilaku anak. ${ }^{41}$ Hasil testimoni beberapa orang tua wali murid ini disampaikan dengan dua sebab yang berbeda. ${ }^{42}$ Sebab pertama adalah orang tua murid yang menyekolahkan anaknya dari awal, artinya sebelum anaknya sekolah di SDIT SUIS akhlaknya belum bagus, tetapi setelah anaknya sekolah di SDIT SUIS akhlaknya menjadi bagus dan terus mengalami

\footnotetext{
${ }^{39}$ Hasil Wawancara dengan Wakil Kepala Sekolah Bidang Kurikulum SDIT SUIS Bogor Aji Mustopa, pada tanggal 22 Oktober 2020.

${ }_{40}$ Berdasarkan Data Dokumentasi SDIT SUIS 2018.

${ }^{41}$ Hasil Wawancara dengan Beberapa Orang tua Murid Terkait dengan Perkembangan dan Perilaku Peserta Didik, tanggal 21 Oktober 2020.

42 Hasil Wawancara dengan Beberapa Orang tua Murid Terkait dengan Perkembangan dan Perilaku Peserta Didik, tanggal 21 Oktober 2020. Wawancara dilakukan secara acak. 182 | IQ (Ilmu Al-qur'an): Jurnal Pendidikan Islam| Volume 4 No. 022021
} 
peningkatan dari waktu ke waktu. Sebab kedua adalah orang tua murid yang anaknya pindahan dari sekolah lain, sebelum pindah ke SDIT SUIS akhlaknya kurang bagus tetapi setelah pindah ke SDIT SUIS akhlaknya menjadi lebih bagus.

Konsep program ini mengkondisikan peserta didik untuk mengikuti kegiatan pembiasaan menjalankan amalan-amalan sunnah dan adab-adab Islami yang didukung dengan keteladanan dan monitoring dari guru dan orang tua murid. ${ }^{43}$ Sepintas kegiatan ini kelihatan sederhana dan tidak terkonsep dengan mapan, namun di SDIT SUIS program ini terkonsep dengan baik. Secara teori program ini mudah dilaksanakan tetapi secara praktik membutuhkan kesadaran dan kesungguhan serta upaya yang kuat dari guru dan orang tua.

Teori yang mendasari perencanaan pembelajaran di SDIT SUIS menggunakan pendekatan bahwa guru adalah orang tua peserta didik di sekolah. Peran guru sebagai orang tua di sekolah memiliki relasi yang kuat dengan peserta didik. Hubungan peserta didik dan guru menjadi lebih dekat. Hubungan guru dan peserta didik sangat menentukan ketercapaian hasil pembelajaran. ${ }^{44}$ Ibnu Athoilah berpendapat bahwa relasi guru-murid menciptakan pembelajaran yang humanis dan spirit ruhaniah. ${ }^{45}$

Perencanaan pembelajaran di SDIT SUIS sesuai pendapat Nashih Ulwan ${ }^{46}$ bahwa dalam siklus kehidupan manusia masa kanak-kanak adalah periode yang paling penting dan paling berbahaya, untuk itu memerlukan perhatian dan kesungguhan dari pihak-pihak yang bertanggungjawab terhadap pendidikan anak, dalam hal ini adalah orang tua dan guru. Kemudian diperlukan metode yang efektif dalam menanamkan akhlak kepada anak. orang tua harus berupaya membentuk dan mempersiapkan anak secara mental dan moral, saintikal, spiritual, dan sosial, sehingga peserta didik dapat mencapai kematangan yang sempurna. Metode tersebut adalah pendidikan dengan keteladanan, pendidikan dengan pembiasaan, pendidikan dengan nasihat, pendidikan dengan memberikan perhatian, dan pendidikan dengan memberikan hukuman.

Di dalam perencanaan pembelajaran di SDIT SUIS lebih memfokuskan hanya pada dua metode, yaitu pendidikan dengan keteladanan dan pendidikan dengan pembiasaan. ${ }^{47}$ Kedua

\footnotetext{
${ }^{43}$ Hasil Wawancara dengan Wakil Kepala Sekolah Bidang Kurikulum SDIT SUIS Bogor Aji Mustopa, pada tanggal 22 Oktober 2020.

${ }^{44}$ Imam Suwardi Wibowo dan Ririn Farnisa, "Hubungan Peran Guru Dalam Proses Pembelajaran Terhadap Prestasi Belajar Siswa”, Jurnal Gentala Pendidikan Dasar, (2018), vol. 3, no. 2, 183.

${ }^{45}$ Muhammad Nurdin, Muhammad Harir Muzakki, Sutoyo, "Relasi Guru dan Murid (Pemikiran Ibnu 'Athaillah Dalam Tinjauan Kapitalisme Pendidikan)”, Kodivikasi, (2015), vol. 9. no. 1, 122-144.

${ }^{46}$ Erfa Ernawati, "Metode Pendidikan Akhlak Anak Dalam Perspektif Nashih Ulwan dan Relevansinya Dengan Kondisi Saat ini”, Adabiyah: Journal of Islamic Education, (2017), vol. 2, no. 1, 116.

${ }^{47}$ Hasil Wawancara dengan Wakil Kepala Sekolah Bidang Kurikulum SDIT SUIS Bogor pada tanggal
} 20 Oktober 2020. 
metode tersebut diakui efektif dalam membentuk akhlak dan moral pada anak. pada kondisi saat ini moral lebih dikedepankan ketimbang ilmu, karena adakalanya ilmu dapat menggelincirkan seseorang pada kerusakan moral. Teknologi yang canggih dan serba cepat jika tidak didasari dengan moral yang kuat hanya akan dimanfaatkan untuk hal-hal yang cenderung negatif. Demikian pula sebaliknya teknologi yang canggih dapat diarahkan ke halhal yang positif apabila seorang peserta didik memiliki moral yang baik.

Meskipun hanya dua metode yang dijalankan oleh SDIT SUIS, namun metode yang lainnya seperti pendidikan dengan nasihat, pendidikan dengan perhatian, dan pendidikan dengan hukuman tetap dijalankan sesuai dengan kebutuhan. SDIT SUIS memandang bahwa pendidikan dengan keteladanan dan pembiasaan merupakan tahapan paling prioritas dalam pembentukan karakter dan kecerdasan spiritual.

\section{Proses dan Metode Pembelajaran Dalam Membentuk Karakter dan Kecerdasan Emosional Peserta Didik di SDIT SUIS Bogor}

Proses dan metode pembelajaran di SDIT SUIS dapat dikelompokkan sebagai berikut:

\section{a. Pelaksanaan KBM}

Pelaksanaan KBM dititik beratkan pada RPP yang telah dibuat oleh guru berdasarkan pedoman kurikulum 2013. Kepala Sekolah dan Wakil Kepala Sekolah Bidang Kurikulum SDIT SUIS mengawal proses pembelajaran dengan melakukan pengontrolan yang ketat pada pelaksanaan KBM. Setiap guru diharapkan dapat menguasai kelas dan memilih metode yang tepat dalam mengajar. ${ }^{48}$ Metode mengajar yang digunakan oleh setiap guru berbeda-beda, tergantung pada mata pelajaran yang diampu.

Untuk mata pelajaran PAI dan Budi Pekerti, Akidah, dan Akhlak, dilaksanakan di dalam kelas, sedangkan mata pelajaran Al-Qur'an, Fikih, dan Kisah Anak sholeh dilaksanakan di luar kelas. Pelaksanaan KBM disesuaikan dengan masing-masing mata pelajaran. Mata pelajaran yang dilaksanakan di kelas tingkat ketercapainnya diukur dari keaktifan peserta didik dalam diskusi. Teknik diskusi di kelas dilakukan dengan beberapa metode. Metode pertama guru bertanya kepada peserta didik setelah selesai menjelaskan materi. Pertanyaan guru bertujuan untuk mengkonfirmasi peserta didik, apakah ia paham dengan materi yang dijelaskan atau tidak. Peserta didik yang belum paham diberikan kesempatan untuk bertanya. Peserta didik yang mengajukan pertanyaan kepada guru tentang suatu hal yang belum ia pahami,

\footnotetext{
${ }^{48}$ Hasil Wawancara dengan Kepala Sekolah dan Wakil Kepala Sekolah Bidang Kurukulum SDIT SUIS Bogor, pada tanggal 20 Oktober 2020.

184 | IQ (Ilmu Al-qur'an): Jurnal Pendidikan Islam| Volume 4 No. 022021
} 
kemudian guru memberikan jawaban, maka hal itu mengindikasikan bahwa peserta didik yang bersangkutan menyimak dan memperhatikan penjelasan guru. Setelah ia mendapatkan jawaban dari guru maka peserta didik tersebut dianggap memahami materi lebih dari 75\%.

Bagi peserta didik yang tidak mengajukan pertanyaan dapat dikelompokkan menjadi dua; kelompok yang pertama mereka tidak mengajukan pertanyaan karena memang sesungguhnya mereka sudah paham, dan kelompok yang kedua mereka tidak mengajukan pertanyaan tapi sesungguhnya mereka tidak paham. Kelompok yang kedua ini sulit diukur ketercapaiannya apabila guru tidak melakukan tindakan setelahnya. Metode yang kedua guru mengkonfirmasi peserta didik yang tidak mengajukan pertanyaan atau mereka mengaku sudah paham dengan memberikan pertanyaan kepada mereka. Pertanyaan disampaikan kepada peserta didik secara acak, hanya diperlukan dua sampai tiga orang saja sebagai sempel. Hal tersebut untuk mengkonfirmasi secara umum bahwa mereka paham. Dengan demikian target pembelajaran tercapai dengan baik. Metode ketiga guru melemparkan suatu opini tertentu yang terkait dengan mata pelajaran yang diampu, yang diharapkan di sini adalah umpan balik dari peserta didik, apabila mereka tertarik untuk memberikan pendapat maka hal tesebut menjadi tolok ukur keberhasilan peserta didik. ${ }^{49}$

Dalam pelaksanaan KBM yang paling sulit adalah menghidupkan kelas dan menguasai kelas. Guru harus menggunakan metode yang berbeda-beda untuk memastikan bahwa kelas hidup dan peserta didik terlibat aktif dalam pembelajaran.

Tuntutan yang paling berat bagi guru dalam pelaksanaan pembelajaran adalah bagaimana guru dapat menyelesaikan silabus yang telah ia buat untuk 23 atau 24 kali pertemuan dalam satu semester. Kendala yang paling sulit adalah masing-masing buku yang dijadikan referensi utama mata pelajaran berbeda-beda ketebalannya. Guru harus membagi dengan baik silabus dari buku referensi utama tersebut secara proporsional untuk memastikan seluruh materi pada buku tersebut tersampaikan. ${ }^{50}$

Pelaksanaan KBM di luar kelas ketercapaiannya lebih efektif. Keterlibatan peserta didik dalam mengikuti KBM lebih hidup, karena mau tidak mau peserta didik harus mengikuti praktik yang ditunjukkan oleh guru. Ketika guru mengajar mata pelajaran fikih ibadah kemudian yang dibahas adalah praktik wudhu misalnya, peserta didik terlihat lebih antusias. Pada pelaksanaannya terkadang sulit dikondisikan atau beberapa peserta didik ribut satu sama lain, namun mereka tetap kompak dan semangat.

\footnotetext{
${ }^{49}$ Hasil Wawancara dengan Kepala Sekolah SDIT SUIS Bogor, pada tanggal 20 Oktober 2020.

${ }^{50}$ Hasil Wawancara dengan Wakil Kepala Sekolah SDIT SUIS Bogor, pada tanggal 20 Oktober 2020.
} 
Kesulitan yang dihadapi oleh guru dalam mengkondisikan peserta didik lebih sulit ketika KBM dilaksanakan di luar kelas, namun ketercapaian pembelajarannya lebih tinggi. Untuk mata pelajaran yang sifatnya praktik penulis menyarankan agar dilaksanakan oleh tim.

b. Pelaksanaan Keteladanan dan Pembiasaan

Pelaksanaan secara teknis program keteladanan dan pembiasaan secara teori lebih mudah karena setiap guru telah diberikan buku pedomannya. Sesungguhnya yang paling sulit dalam paling sulit pada program ini adalah keteladanan yang dibangun oleh guru. ${ }^{51}$ Kunci kesuksesannya adalah apabila seorang guru maksimal dalam memberikan keteladanan. Keteladanan dalam melaksanakan amal sholeh harus didorong oleh tingkat keimanan dan tingkat pengetahuan seorang guru terhadap amal sholeh tersebut. Motivasi keimananlah yang kuat mempengaruhi seorang guru dalam melaksanakan amal sholeh. Ilmu saja tidaklah cukup. Keteladanan harus disajikan secara kompak oleh setiap guru dan dilakukan secara konsisten, sehingga nantinya akan menjelma menjadi budaya kerja guru yang sangat ideal. Masalah yang timbul pada pelaksanaan keteladanan dipengaruhi oleh dua hal; yaitu tingkat keimanan dan tingkat pengetahuan guru. ${ }^{52}$ Dua hal tersebut merupakan motivasi utama seorang guru untuk membangun keteladanan. Sebuah contoh misalkan guru yang kebiasaan shalat berjamaahnya selalu terlambat, maka secara otomatis ia pun akan sering terlambat karena hal tersebut sudah menjadi karakter pada dirinya. Dan sebaliknya apabila seorang guru sudah terbiasa shalat berjamaah di awal waktu, maka ia akan mudah mengamalkan keteladanan ini.

Penulis menyarankan agar program keteladanan guru ini membutuhkan pembianaan yang intensif agar nantinya guru lebih mudah memberikan keteladanan pada peserta didik. Apabila tingkat keimanan dan keilmuan setiap guru seimbang, maka akan terjadi kekompakan dalam keteladanan yang mendukung program pembiasaan kepada peserta didik menjadi sangat ideal dan hasilnya lebih maksimal.

Sedangkan program keteladanan dan pembiasaan yang dilakukan orang tua kepada peserta didik jauh lebih berat, karena orang tua tidak dipantau secara langsung oleh guru atau pihak sekolah yang bertanggungjawab. Orang tua hanya dibekali buku muhasabah saja oleh sekolah. Program keteladanan dan pembiasaan peserta didik ketika di rumah membutuhkan motivasi dan kesadaran yang tinggi bagi orang tua.

Pada program yang dilakukan orang tua ini penulis menyarankan agar pihak sekolah memberikan program pembinaan yang dilakukan secara intensif agar orang tua sadar

\footnotetext{
${ }^{51}$ Hasil Wawancara dengan Kepala Sekolah SDIT SUIS Bogor, pada tanggal 20 Oktober 2020.

${ }^{52}$ Hasil Wawancara dengan Wakil Kepala Sekolah SDIT SUIS Bogor, pada tanggal 20 Oktober 2020. 186 | IQ (Ilmu Al-qur'an): Jurnal Pendidikan Islam| Volume 4 No. 022021
} 
sepenuhnya untuk membimbing anaknya dalam melaksanakan program ini. Sebaiknya setiap guru juga harus melakukan kunjungan ke rumah orang tua minimal satu bulan sekali untuk memonitoring dan mengevaluasi program ini agar lebih maksimal lagi. Program keteladanan dan pembiasaan harus memiliki perhatian khusus, agar pembentukan karakter dan kecerdasan spiritual peserta didik tercapai.

1. Evaluasi Pembelajaran Dalam Membentuk Karakter dan Kecerdasan Emosional Peserta Didik di SDIT SUIS Bogor

Pada evaluasi pembelajaran berbasis pendidikan rabbani yang dilaksanakan di SDIT SUIS Bogor, penulis fokus menganalisis data peserta didik pada Tahun Pelajaran 2019/2020 yang dilakukan di semua kelas mulai dari kelas 1 sampai dengan kelas 6. Nilai rata-rata hasil pembelajaran hanya difokuskan pada enam mata pelajaran saja, yaitu; Al-Qur'an, PAI dan Budi Pekerti, Aqidah, Kisah Anak Shaleh, Fikih, dan Akhlak. ${ }^{53}$ Argumentasi tersebut didasarkan pada enam mata pelajaran Ke-Islaman unggulan di SDIT SUIS. ${ }^{54}$ Profil dan nilai rata-rata peserta didik pada Tahun Pelajaran 2019/2020 dapat digambarkan pada tabel di bawah ini.

Tabel $4.10^{55}$

\begin{tabular}{|c|c|c|c|c|c|c|c|c|c|c|c|c|c|c|c|}
\hline \multicolumn{16}{|c|}{$\begin{array}{l}\text { Rekap Nilai Rata-Rata Peserta Didik SDIT SUIS Bogor } \\
\text { Tahun Pelajaran 2019/2020 }\end{array}$} \\
\hline Kelas & & $1 \mathrm{~A}$ & $1 \mathrm{~B}$ & $2 \mathrm{~A}$ & $2 B$ & $3 \mathrm{~A}$ & $3 B$ & $4 \mathrm{~A}$ & $4 \mathrm{~B}$ & $4 C$ & $5 \mathrm{~A}$ & $5 B$ & $6 \mathrm{~A}$ & $6 B$ & \multirow{2}{*}{ NR } \\
\hline Jumlah Siswa & & 32 & 31 & 22 & 26 & 29 & 29 & 26 & 20 & 19 & 10 & 20 & 31 & 15 & \\
\hline Al-Qur'an & & 82 & 83 & 86 & 78 & 84 & 83 & 82 & 84 & 82 & 88 & 86 & 87 & 82 & 83 \\
\hline PAI \& BP & & 91 & 89 & 86 & 85 & 83 & 83 & 83 & 87 & 85 & 85 & 85 & 82 & 89 & 85 \\
\hline Aqidah & & 92 & 92 & 87 & 84 & 82 & 81 & 80 & 86 & 84 & 84 & 90 & 90 & 86 & 86 \\
\hline Kisah Anak Shaleh & & 93 & 97 & 86 & 87 & 86 & 81 & 87 & 88 & 88 & 88 & 91 & 93 & 88 & 88 \\
\hline Fikih & & & & & & 82 & 87 & 90 & 86 & 88 & 88 & 88 & 86 & 85 & 86 \\
\hline \multirow{2}{*}{ Akhlak } & Sosial & 3 & 4 & 4 & 3 & 4 & 4 & 4 & 4 & 3 & 4 & 4 & 3 & 3 & 4 \\
\hline & Spiritual & 4 & 3 & 4 & 3 & 4 & 4 & 4 & 4 & 3 & 4 & 4 & 3 & 4 & 4 \\
\hline
\end{tabular}

Pada Tahun Pelajaran 2019/2020 SDIT SUIS memiliki 13 rombongan belajar (rombel) dengan jumlah peserta didik sebanyak 310 siswa dengan jumlah sebaran di setiap rombel yang variatif. Rasio rombel yang paling ideal menurut Permendikbud Nomor 17 Tahun 2017 Pasal 24, untuk jenjang SD, di dalam satu kelas jumlah peserta didik paling sedikit ialah 20 dan paling banyak ialah 28 peserta didik. Jumlah peserta didik pada kelas 1 A 32 siswa dan 1 B 31 , jumlah ini melebihi angka maksimal rombel, pada kelas 1 A memiliki kelebihan 4 siswa dan

\footnotetext{
${ }^{53}$ Hasil Studi Dokumentasi, Rekap Nilai Rata-Rata Peserta Didik SDIT SUIS Bogor Tahun Pelajaran 2019/2020 pada tanggal 24 Oktober 2020.

54 Hasil Studi Dokumentasi, Rekap Nilai Rata-Rata Peserta Didik SDIT SUIS Bogor Tahun Pelajaran 2019/2020 pada tanggal 24 Oktober 2020.

55 Hasil Studi Dokumentasi, Rekap Nilai Rata-Rata Peserta Didik SDIT SUIS Tahun Pelajaran 2019/2020 untuk Enam Mata Pelajaran Berbasis Al-Qur'an pada tanggal 24 Oktober 2020.
} 
pada kelas 1 B memiliki kelebihan 3 siswa. Jumlah peserta didik yang over capacity di dua rombel tersebut dinilai tidak ideal.

Pada kelas 2 A 22 siswa dan kelas 2B 26 siswa, dua rombel tersebut cukup ideal jumlahnya. Pada kelas 3 A 29 siswa dan kelas 3 B 29 siswa, dua rombel tersebut masingmasing memiliki kelebihan 1 siswa. Pada kelas 4 A 26 siswa, 4 B 20 siswa, dan 4 C 19 siswa jumlah rombel kelas 4 A dan 4 B cukup ideal, sedangkan jumlah siswa pada kelas 4 C kurang 1 siswa. Pada kelas 5 A 10 siswa dan 5 B 20 siswa. Jumlah siswa pada rombel 5 A sangat sedikit dan rombel pada 5B cukup ideal. Pada kelas 6 A 31 siswa dan 6 B 15 siswa. Jumlah siswa pada rombel 6 A meimiliki kelebihan 3 siswa dan jumlah siswa pada rombel $6 \mathrm{~B}$ kekurangan 5 siswa.

Terdapat 5 rombel yang jumlah siswanya ideal yaitu; rombel kelas 2 A, 2 B, 4 A, 4 B, dan 5 B. terdapat 5 rombel yang kelebihan siswa yaitu; 1 A, 1 B, 3 A, 3B, dan 6 A. Terdapat tiga rombel yang kekurangan siswa yaitu; 4 C, 5A, dan 6 B. Jumlah rasio rombel di SDIT SUIS Bogor perlu diperbaiki lagi. Sistem rekrutmen peserta didik baru harus memperhatikan rasio ideal untuk standar rombel jenjang sekolah dasar. Kecukupan jumlah rombel dan siswa dalam satu rombel harus disesuaikan dengan daya tampung kelas.

Sekolah dapat mengkalkulasi jumlah kelas yang ada kemudian diperkirakan daya tampungnya berapa paling maksimal. Paling maksimal tidak boleh melebihi 28 siswa dalam satu kelas, oleh karena itu jumlah siswa paling maksimal yang akan direkrut adalah 28 siswa, dan perlu diperhatikan pula jumlah minimal siswa dalam satu rombel, yaitu 20 siswa, oleh sebab itu diupayakan jumlah siswa dalam satu rombel tidak boleh kurang dari 20. Rasio jumlah siswa dalam satu kelas sudah diukur volumenya, jika siswanya melebihi jumlah yang ideal, maka siswa akan berdesak-desakan di kelas yang membuat suasana belajar peserta didik tidak nyaman dan tidak kondusif. Hal tersebut tentunya dapat menurunkan kualitas pembelajaran.

Begitu pula jika jumlah siswa terlalu sedikit dalam satu rombel, hal tersebut membuat peserta didik kurang semangat dalam belajar, sebab ia merasa bahwa teman satu angkatannya hanya sedikit, dan hal tersebut dapat menurunkan kualitas pembelajaran. Kekurangan jumlah siswa dalam satu rombel misalkan hanya satu atau dua orang masih dipandang ideal, tetapi apabila lebih banyak dari itu menjadi tidak ideal lagi.

Penulis mengkritisi pada sebaran siswa di setiap rombel harus diperhatikan lebih serius lagi oleh pihak pemangku kepentingan. Walaupun jumlah rombel yang kurang ideal tersebut terbukti tidak terlalu berpengaruh terhadap prestasi pembelajaran peserta didik. namun perlu 
diperhatikan dan dipertimbangkan ke depannya untuk menjamin mutu pembelajaran peserta didik, sehingga prestasi pembelajaran terus dapat ditingkatkan.

Nilai rata-rata peserta didik pada Tahun Pelajaran 2019/2020 sangat baik dengan jumlah ratarata 85,6. Dari sini dapat disimpulkan bahwa rata-rata nilai peserta didik mencapai target yang ideal. Setiap nilai dari masing-masing mata pelajaran tersebut, juga mencerminkan sikap sosial atau karakter, dan sikap spiritual atau kecerdasan spiritual. Nilai yang tergambar pada mata pelajaran akhlak menunjukkan bahwa tingkat pencapaian pembentukan karakter peserta didik mencapai nilai maksimal yaitu $4^{56}$, sedangkan untuk kecerdasan spiritual mencapai nilai maksimal yang sama yaitu 4 . Angka 4 tersebut adalah pembulatan 3,58 untuk sikap sosial dan 3,70 untuk sikap spiritual.

Sebaran nilai rata-rata untuk mata pelajaran Al-Qur'an adalah 83, sebaran nilai ratarata untuk mata pelajaran PAI dan Budi Pekerti adalah 85, sebaran nilai rata-rata untuk mata pelajaran Aqidah adalah 86, sebaran nilai rata-rata untuk mata pelajaran Kisah Anak Shaleh adalah 88, sebaran nilai rata-rata untuk mata pelajaran Fikih 86, dan sebaran nilai rata-rata untuk mata pelajaran Akhlak untuk sikap sosial adalah 3,58, dan sikap spiritual 3,70. Pencapain nilai rata-rata peserta didik pada tahun pelajaran tersebut sangat baik. Khusus untuk nilai ratarata mata pelajaran Al-Qur'an harus lebih ditingkatkan lagi, karena nilainya masih di bawah 85. Hal tersebut disebabkan sebaran nilai rata-rata pada kelas 2 B adalah 78. Perlu dilakukan evaluasi pembelajaran khusus untuk guru-guru yang mengampu mata pelajaran Al-Qur'an pada kelas tersebut.

Berdasarkan paparan data di atas dapat disimpulkan bahwa capaian kompetensi pembelajaran peserta didik pada enam mata pelajaran tersebut telah sesuai dengan harapan. Model pembelajaran berbasis Al-Qur'an yang diperkuat dengan program keteladanan dan pembiasaan menghasilkan pembentukan karakter dan kecerdasan spiritual pada paserta didik. Karakter yang paling menonjol pada peserta didik adalah jujur, disiplin, tanggungjawab, santun, peduli, percaya diri dalam berinteraksi ketika di sekolah, di rumah, dan di masyarakat, dan hormat dan patuh pada orang tua dan guru. ${ }^{57}$ Kemudian kecerdasan spiritual yang sangat menonjol pada peserta didik adalah ketaatan dalam menjalankan ajaran Islam seperti shalat lima waktu secara berjamaah, sholat dhuha, rajin membaca dan menghafal Al-Qur'an, dzikir

${ }^{56}$ Metode Penilaian Sikap Sosial dan Sikap Spiritual dibedakan dengan lima mata pelajaran yang lain. Berdasarkan Studi Dokumentasi pada tanggal 24 Oktober 2020.

${ }^{57}$ Berdasarkan Hasil Wawancara dengan Kepala Sekolah dan Wakil Kepala Sekolah Bidang Kurikulum SDIT SUIS Bogor, pada tanggal 20 Oktober 2020. 
pagi dan petang, berdoa setiap melakukan aktifitas, berinfak dan membaca surat Al-Kahfi pada hari Jumat. ${ }^{58}$

Keberhasilan pendidikan rabbani dalam pembentukan karakter dan kecerdasan spiritual pada peserta didik di SDIT SUIS Bogor didukung oleh data-data yang sahih dan terukur berdasarkan penilaian yang dilakukan oleh sekolah, dan berdasarkan testimoni dari beberapa orang tua. ${ }^{59}$ Namun, demikian masih ada beberapa kekurangan dan kelemahan dalam perencanan pembelajaran, pelaksanaan pembelajaran, dan evaluasi pembelajaran yang sudah diulas satu persatu oleh penulis berdasarkan fakta dan temuan di lapangan.

\section{Kesimpulan}

Berdasarkan fakta, temuan, dan hasil pembahasan, penelitian ini menyimpulkan bahwa konsep pendidikan Berbasis Al-Qur'an yang diselenggarakan di SDIT SUIS Bogor terbutkti efektif dalam pembentukan karakter dan kecerdasan spiritual peserta didik.

1. Proses pembentukan karakter dilakukan dengan memfokuskan pembelajaran pada enam mata pelajaran yang dijadikan unggulan, di antaranya adalah Mata Pelajaran Al-Qur'an, Pendidikan Agama Islam dan Budi Pekerti, Aqidah, Kisah Anak Shaleh, Fikih, dan Akhlak. Pelaksanaan KBM pada enam mata pelajaran tersebut diperkuat dengan Program Keteladanan dan Pembiasaan yang melibatkan guru dan orangtua siswa. Model kegiatan ketedanan dan pembiasaan dicontohkan terlebih dahulu oleh guru dan orangtua siswa, karena pada fase usia anak tujuh tahun kedua, mereka lebih fokus menggunakan penglihatannya untuk menduplikasi setiap kegiatan yang dirasa menarik untuk ditiru dalam proses pembelajaran. SDIT SUIS berkeyakinan pola ini sangat tepat diterapkan sebagai strategi pembelajaran dalam rangka pembentukan karakter peserta didik. Kemudian program ini dirancang sedemikian rupa untuk memperkuat kompetensi enam mata pelajaran yang ada dalam rangka ketercapaian sikap sosial yang kemudian diterjemahkan menjadi character building. Karakter yang paling menonjol pada peserta didik adalah jujur, disiplin, tanggungjawab, santun, peduli, percaya diri dalam berinteraksi ketika di sekolah, di rumah, dan di masyarakat, dan hormat dan patuh pada orangtua dan guru. Pada target pembentukan karakter, nilai yang diperolah sangat baik yaitu 3,58 .

\footnotetext{
${ }^{58}$ Berdasarkan Hasil Wawancara dengan Wakil Kepala Sekolah Bidang Kurikulum SDIT SUIS Bogor, pada tanggal 20 Oktober 2020.

${ }_{59}$ Berdasarkan Hasil Studi Dokumentasi di SDIT SUIS Bogor.

190 | IQ (Ilmu Al-qur'an): Jurnal Pendidikan Islam | Volume 4 No. 022021
} 
2. Pembangunan kecerdasan spiritul lebih didominasi oleh porsi Mata Pelajaran Al-Qur'an yang didukung pula dengan nilai-nilai lima mata pelajaran yang lain dan didorong kuat dengan program keteladanan dan pembiasaan yang didampingi oleh guru dan orangtua siswa. kecerdasan spiritual yang sangat menonjol pada peserta didik adalah ketaatan dalam menjalankan ajaran Islam seperti sholat lima waktu secara berjamaah, sholat dhuha, rajin membaca dan menghafal Al-Qur'an, dzikir pagi dan petang, berdoa setiap mengawali aktifitas, berinfak dan membaca surat Al-Kahfi pada hari Jumat. Pada target pembangunan kecerdasan spiritual nilai yang diperoleh lebih besar dari pembentukan karakter yaitu 3,70. Dengan hasil yang sangat baik ini membuktikan bahwa teori Nashih Ulwan tentang pendidikan keteladanan dan pembiasaan sangat efektif dalam pembentukan karakter dan kecerdasan spiritual pada peserta didik di SDIT SUIS Bogor.

3. Berdasarkan hasil dari analisis SWOT, yang menjadi kekuatan pada konsep pembelajaran berbasis Al-Qur'an di SDIT SUIS Bogor adalah pola perencanaan pembelajaran yang berfokus menumbuhkan dan mengokohkan peserta didik dengan memperbanyak porsi pembelajaran Al-Qur'an yang didukung dengan lima mata pelajaran diniyah lainnya serta dikuatkan dengan program keteladanan dan pembiasaan yang melibatkan guru dan orangtua siswa. Kemudian pengawalan pelaksanaan KBM yang sangat ketat oleh pimpinan sekolah sehingga efektif mencapai target pembelajaran. Kelemahan model pembelajaran ini membutuhkan upaya yang kuat dari guru dan orangtuasiswa dalam mengawal pelaksanaannya. Keteladanan dan pembiasaan yang dibangun harus konsisten dan bersifat terus menerus. Peluangnya adalah potensi pembelajaran yang berbasis keteladanan dan pembiasaan dapat meningkatkan akhlak peserta didik secara signifikan. Ancamannya pada era digital yang serba canggih dan serba cepat orangtua siswa tidak mampu membatasi dan mengendalikan anak dalam bermain gadget atau smartphone yang menyebabkan anak menjadi malas dan lambat untuk belajar. Kemudian ancaman berikutnya adalah tingkat kesadaran dari orangtua yang rendah terhadap program pembelajaran ini mengakibatkan kondisi peserta didik ketika di rumah justru mengalami kemunduran.

\section{Saran}

1. Model pendidikan berbasis Al-Qur'an yang melibatkan guru dan orangtua siswa dalam program keteladanan dan pembiasaan harus dirumuskan bersama antara sekolah dengan orangtua siswa. Hal tersebut untuk mencermati secara mendalam kendala-kendala yang dirasakan oleh orangtua siswa ketika melaksanakan program pembisaan dan keteladanan. 
2. Struktur kurikulum, RPP, dan silabus harus lebih disederhanakan untuk mengefektifkan rencana pembelajaran, pelaksanaan pembelajaran, dan evaluasi pembelajaran.

3. SDIT SUIS Bogor harus memiliki metode yang tepat dalam membangun kesadaran orangtua bahwa pendidikan anak merupakan tanggungjawab bersama antara orangtua dengan sekolah. Hubungan sekolah dengan orangtua adalah partner yang sama-sama bersinergi dalam mendidik anak.

4. Program penguatan dalam membentuk akhlakul karimah akan lebih maksmimal jika menerapkan empat metode pendidikan anak berdasarkan teori Nashih Ulwan, yaitu: Pendidikan Keteladanan, Pendidikan, Pembiasaan, Pendidikan dengan Nasihat, Pendidikan dengan Perhatian, dan Pendidikan dengan Hukuman.

\section{DAFTAR PUSTAKA}

'Ali as-Shobuny, Muhammad. (1996). Shoffawah at-Tafaasir. Mesir: Dar as-Shobuny. Affan, M. Husin Hafidh Maksum. (2016). Membangun Kembali Sikap Nasionalisme Bangsa Indonesia Dalam Menangkal Budaya Asing di Era Globalisasi. Jurnal Pesona Dasar. (3). 4.

Ainiyah, Nur. (2013). Pembentukan Karakter Melalui Pendidikan Agama Islam. Jurnal AlUlum. (13). 1.

Aisyah. (2018). Pendidikan Karakter: Konsep dan Implementasinya. Jakarta: Kencana.

Al Qurthuby, Abu 'Abdillah Muhammad Syamsuddin. (1964). Tafsir Al-Qurthuby. Mesir: Dar Al Kutub Al Mishriyyah.

al-Baghowy, Abu Muhammad al-Husain. (1999). Tafsir al-Baghowy. Beirut: Dar Ihya atTurots.

Al-Bukhori, Muhammad Bin Ismail Shohih Al Bukhori. (2001). Damaskus: Daru Qauthin Najaah.

Al-Ifriqy, Muhammad bin Mukrim. (1994). Lisaan Al 'Araby. Beirut: Daaru Shodir.

Al-Munir, Wahbah az-Zuhaili. (1997). Damaskus: Dar al-Fikr al-Ma'aashir.

al-Naisabury, Muslim bin al-Hajjaj. (2009). Beirut: Dar Ihya at-Turots al-‘aroby.

Amin, Misbahudin. (2017). Kompetensi Guru Dalam Menanamkan Nilai-Nilai Akhlak Mulia

Dalam Pembelajaran PAI di Sekolah. Didaktika: Jurnal Kependidikan. (11). 2.

Amos, Nealoka, dkk. (2017). Landasan Pendidikan: Dasar Pengenalan Diri Sendiri Menuju Perubahan Hidup. Jakarta: Kencana. 'Abdillah bin 'Abdirrahman, Abu Muhammad. (2000). Saudi: Dar al-Mughni. 
Implementasi Pendidikan Rabbani dalam Membentuk Karakter dan Kecerdasan Spiritual

Amrah, Sitti. (2018). Karakter Robbani Sebagai Medium Pembentukan Kecerdasan Spiritual

Dalam Proses Pembelajaran (Sebuah Analisis Empiris Pada SDIT Kota Palopo). ElTarbawi: Jurnal Pendidikan Islam. (11). 1.

an-Nahlawi, Abdurahman. (1995). Pendidikan Islam di Rumah, Sekolah, dan Masyarakat. Jakarta: Gema Insani Pres.

Arianti. (2017). Urgensi Lingkungan Belajar yang Kondusif Dalam Mendorong Siswa Belajar Aktif. Didaktika: Jurnlan Kependidikan. (11). 1.

As Sijistan, Abu Daud Sulaiman bin Al Asy'at. (2008). Beirut: Al-Maktabah Al 'Ishriyyah. at-Thusi, Abu Hamid Muhammad bin Muhammad al-Ghazali. (2004). Ihya 'Ulumuddiin. Beirut: Darul Ma'rifah.

Atabik, Ahmad dan Ahmad Burhanuddin. (2015) Konsep Nasih Ulwan Tentang Pendidikan Anak. Elementary. (3). 2.

Ath-Thabary, Abu Ja'far. (2000). Tafsir Ath-Thabary. Mesir: Muassasah Ar-Risalah.

Bandur, Agustinus. (2016). Penelitian Kualitatif, Metodologi, Desain, dan Teknik Analisis Data dengan NVIVO 11 Plus. Jakarta: Mitra Wacana.

Bryman, Alan. Social Research Method, Writing Up Social Research.

Bujuri, Dian Andesta. (2018). Analsisis Perkembangan Kognitif Anak Usia Dasar dan Implikasinya dalam Kegiatan Belajar Mengajar. Literasi. (9). 1.

Darajat, Zakiah dkk. (2014). Ilmu Pendidikan Islam. Jakarta: Bumi Aksara.

Ernawati, Erfa. (2017). Metode Pendidikan Akhlak Anak Dalam Perspektif Nashih Ulwan dan Relevansinya Dengan Kondisi Saat ini. Adabiyah: Journal of Islamic Education. (2). 1.

Erzad, Azizah Maulana. (2017). Peran Orangtua Dalam Mendidik Anak Sejak Dini Di Lingkungan Keluarga. Thufula. (5). 2.

Fakhrurrazi. (2018). Hakikat Pembelajaran yang efektif. Jurnal At-Tafkir. (11). 1.

Fitriani, Atika dan Eka Yanuarti. (2018) Upaya Guru Pendidikan Agama Islam Dalam Menumbuhkan Kecerdasan Spiritual Siswa Belajea: Jurnal Pendidikan Islam. (3). 2.

Hamka. (1983). Tafsir al-Azhhar. Jakarta: Pustaka Panjimas.

Hanum, Latifah. (2016). Strategi Belajar Mengajar: Konsep Strategi Belajar Mengajar, Hakikat Belajar dan Pembelajaran, Model-Model Pembelajaran, Pendekatan Dalam Pembelajaran, Metode Mengajar, Sumber Belajar, Pengelolaan Kelas, Keberhasilan Belajar Mengajar, Pengajaran Remedial dan Pelayanan. Yogyakarta: Deepublish.

Hartono. (2013). Konsep Belajar dan Pembelajaran Menurut Surat An-Nahl Ayat 78. Insania. (18). 2. 
Nasrulloh

Hidayah, Nurul. Manajemen Pembentukan Karakter Melalui Kegiatan Kepanduan Hizbul Wathan di SMP Muhammadiyah 1 Klaten Tahun Pelajaran 2018/2019. Tesis.

Hidayat, Tatang dan Abas Asyafah. (2019). Konsep Dasar Evaluasi dan Implikasinya Dalam Evaluasi Pembelajaran Agama Islam di Sekolah. At-Tadzkiyah: Jurnal Pendidikan Agama Islam. (10). 1.

Ismanto. (2014). Evaluasi Hasil Belajar Pendidikan Agama Islam (PAI) Edukasia: Jurnal Penelitian Pendidikan Islam. (9). 2.

Izan, Ahmad, Saehudin. Tafsir Pendidikan: Konsep Pendidikan Berbasis Al-Qur'an. Yogyakarta: Perpustakaan Magister Studi Islam UII.

Johar, Rahman dan Latifah Hanum. (2016). Strategi Belajar Mengajar: Konsep Strategi Belajar Mengajar, Hakikat Belajar dan Pembelajaran, Model-Model Pembelajaran, Pendekatan Dalam Pembelajaran, Metode Mengajar, Sumber Belajar, Pengelolaan Kelas, Keberhasilan Belajar Mengajar, Pengajaran Remedial dan Pelayanan. Yogyakarta: Deepublish.

Karolina, Asri. (2017). Rekonstruksi Pendidikan Islam Berbasis Pembentukan Karaker, Dari Konsep Menuju Nilai-Nilai Al-Qur'an. Jurnal Penelitian, (11). 2.

Kementerian Pendidikan dan Kebudayaan. (2013). Kurikulum 2013 Kompetensi Dasar Sekolah Dasar (SD)/Madrasah Ibtidaiyah (MI).

Kuswarno, Engkus. Metodologi Penelitian Komunikasi, Fenomenologi: Konsep, Pedoman, dan Contoh Penelitian. Bandung: Widya Padjajaran.

Lase, Delipiter. (2019). Pendidikan di Era Revolusi Industri 4.0. Jurnal Sundermann. (1). 1. Latifah A., Siti Aini. (2012). Proses Pendidikan Agama Islam di SMP Plus Assalam Bandung. Jurnal Tarbawi. (1). 1.

Lilawati, Agustien. (2020). Peran Orangtua Dalam Mendukung Kegiatan Pembelajaran di Rumah Pada Masa Pandemi. Jurnal Obsesi: Jurnal Pendidikan Anak Usia Dini. (1). 1. Maghfiroh, Lailatul. (2017). Membangun Karakter Siswa dan Meningkatkan Kecerdasan Spiritual Melalui The Hidden Curicullum di MI Wahid Hasyim Yogyakarta. Dar El-Ilmi: Jurnal Studi Keagamaan, Pendidikan dan Humaniora. (4), 2.

Majah, Ibnu. (1980). Sunan Ibnu Majah. Beirut: Dar Ihya al-Kutub al-Arabiyyah.

Marliu, Farizal, Otong Surasman, Taufan. (2020). Keteladanan Guru dan Pendidikan Dalam Keluarga Terhadap Kepribadian Muslim Siswa di MTs Pondok Pesantren Al-Husainy Kota Bima. Tajdid: Jurnal Pemikiran Keislaman dan Kemanusiaan. (4). 1. 
Implementasi Pendidikan Rabbani dalam Membentuk Karakter dan Kecerdasan Spiritual

Martina. (2019). Pengaruh Lingkungan Sekolah Terhadap Hasil Belajar Siswa Pada Mata Pelajaran Pendidikan Agama Islam di SMP Negeri 9 Tulung Selapan Kabupaten Oki. Jurnal PAI Raden Fatah. (1). 2.

Medan, Abi dan Ahmad Saputra. (2019). Cahaya Akhlak: Panduan Bagi Pelajar Untuk Memiliki Akhlak yang Mulia, Jawa Timur: Cyber Media Publishing.

Mudjiyanto, Bambang. (2018). Tipe Penelitian Eksploratif Komunikasi. Jurnal Studi Komunikasi dan Media. (22). 1.

Mufatihatut Taubah, "Pendidikan Anak Dalam Keluarga Perspektif Islam”, Jurnal Pendidikan Agama Islam, (2015), Vol. 3, No. 1, 110-136.

Muhadjir, Noeng. (2000). Metodologi Peneltian Kualitatif. Yogyakarta: Rake Sarasin.

Mulyana, Deddy. (2018). Metodologi Penelitian Kualitatif, Paradigma Baru Ilmu Komunikasi dan Ilmu Sosial Lainnya Dilengkapi dengan Contoh-Contoh Penelitian, Bandung: Remaja Rosdakarya.

Muslim bin al-Hajjaj. Shohih Muslim.

Nadzir, M. (2013). Perencanaan Pembelajaran Berbasis Karakter. Jurnal Pendidikan Agama Islam. (2). 2.

Nashih Ulwan, Abdullah. (2019). Pendidikan Anak Dalam Islam Yang Komprehensif. (Bandung: Dilariza.

Ningsih, Tutuk. (2019). Peran Pendidikan Islam Dalam Membentuk Karakter Siswa di Era Revolusi Industri 4.0 Pada Madrasah Tsanawiyah Negeri 1 Banyumas. Insania. (24). 2.

Nizar, Samsul. (2001). Pengantar Dasar-Dasar Pendidikan Islam. Jakarta: Gaya Media Pratama.

Nopianti, Risa. (2018). Pendidikan Akhlak Sebagai Dasar Pembentukan Karakter di Pondok Nurdin, Ismail dan Sri Hartati. (2019). Metodologi Penelitian Sosial. Surabaya: Penerbit Media Cendekia.

Nurdin, Ismail dan Sri Hartati. (2019). Metodologi Penelitian Sosial. Surabaya: Penerbit Media Cendekia.

Nurdin, Muhammad, Muhammad Harir Muzakki, Sutoyo. (2015). Relasi Guru dan Murid (Pemikiran Ibnu ‘Athaillah Dalam Tinjauan Kapitalisme Pendidikan). Kodivikasi. (9). 1.

Nursiah. Peranan Guru Pendidikan Agama Islam Terhadap Peningkatan Prestasi Belajar Peserta Didik Kelas VIII SMP Negeri 1 Poleang Kabupaten Bombana. Tesis UIN Alaudin Makasar.

Parsons, Les (2009). Builled Teacher Builled Student, terj. Grace Worang. Jakarta: Grasindo. Pesantren Sukamanah Tasikmalaya. Jurnal Patanjala. (10). 2. 
Nasrulloh

Pianda, Didi. (2018). Kinerja Guru: Kompetensi Guru, Motivasi Kerja, Kepemimpinan Kepala Sekolah. Sukabumi: CV Jejak.

Pirmanto, Dovel, Muhammad Labib Jundillah, Krisan Aprian Widagdo. (2020). Jenis Penelitian Menurut Kedalaman Analisis Data" Artikel Ilmiah, file:///C:/Users/ASUS/AppData/Local/Temp/Penelitian_Deskriptif_Ekploratori_dan_Ek .pdf, diunduh pada tanggal 12 Oktober 2020.

Pratiwi, Nuning Indah. (2017). Penggunaan Media Video Call Dalam Teknologi Komunikasi. Jurnal Ilmiah Dinamika Sosial. (1). 2.

R., M. Dahlan Lela Qodriah. (2018). Lingkungan Pendidikan Islami dan Hubungannya Dengan Minat Belajar PAI Siswa SMA Negeri 10 Bogor. Edukasi Islami: Jurnal Pendidikan Islam. (7). 2.

Rais, Amien. (2019). Pengembangan Kecerdasan Spiritual Dalam Pendidikan Islam Dengan Pendekatan Neurosains. Muaddib: Studi Kependidikan dan Keislaman. (9). 2.

Ramayulis, (1994). Ilmu Pendidikan Islam. Jakarta: Kalam Mulia.

Rifa'i, Juhdi. (2011). Mengenal Ilmu Hadits. Jakarta: Taushia.

Rosdiana. (2017). Prinsip Dasar Pendidikan Anak Menurut Perspektif Al-Qur'an. Jurnal Idarah. (1). 1.

Rukhayati, Siti. (2020). Strategi Guru PAI Dalam Membina Karakter Peserta Didik SMK AlFalah. Salatiga: Lembaga Penelitian dan Pengabdian Kepada Masyarakat IAIN Salatiga.

S. Sirate, Sitti Fatimah. (2014). Kontruksi Model Pembelajaran Berbasis Kecerdasan Spiritual Untuk Pembentukan Karakter. Jurnal Al-Qalam. (20).

Sadiah, Dewi. (2015). Metode Penelitian Dakwah, Pendekatan Kualitatif dan Kuantitatif. Bandung: Remaja Rosdakarya.

Sapirin dkk. (2019). Implementasi Mata Pelajaran Akidah Akhlak Dalam Pembentukan Karakter Siswa Madarasah Ibtidaiyah Negeri 3 Tapanuli Tengah”, Anthropos. Jurnal Antropologi Sosial dan Budaya. (4). 2.

Sarbini, Muhammad dan Unang Wahidin. (2020). Pendidikan Robbani Untuk Penguatan Karakter Remaja. Jurnal Edukasi Islami. (9). 1.

Siahaan, Monang. Korupsi Penyakit Sosial yang Mematikan. Jakarta: PT Elex Media Komputindo.

Sidek, Baba. (2006). Pendidikan Rabbani: Mengenal Allah Melalui Ilmu Dunia. Selangor: Karya Bestari Sdn. Bhd. 
Implementasi Pendidikan Rabbani dalam Membentuk Karakter dan Kecerdasan Spiritual

Siyoto, Sandu, Ali Sodik. Dasar Metodologi Penelitian. Yogyakarta: Literasi Media Publishing.

Sulastini, Fenty. (2019). Efektifitas Program Tahfidzul Qur'an Dalam Pengembangan Karakter Qur'ani. Jurnal Pendidikan Islam Indonesia. (4). 1.

Sumiyati, Elfa. (2017). Penggunaan Pembelajaran Interaktif Berbasis Aktifitas Untuk Meningkatkan Prestasi Belajar Siswa Kelas VI Pada Pelajaran Pkn SDN 09 Kabawetan. Jurnal PGSD: Jurnal Ilmiah Pendidikan Guru Sekolah Dasar. 66-72.

Suradi, Ahmad. (2018). Sistem Pendidikan Anak Usia Dini Dalam Konsep Islam: Analisis Dalam Teoritis dan Praktis, Al-Athfal: Jurnal Pendidikan Anak. (4). 1.

Surasman, Otong. (2019). Manajemen Pembelajaran Tahfidz Al-Qur'an: Pengalaman Menghafal Al-Qur'an di STIU Ma’had Tahfidz Wadi Mubarak Mega Mendung Bogor. Tarbawiyah: Jurnal Ilmiyah Pendidikan. (2). 2.

Surasman, Otong. (2020). Pendidikan Robbaniyah Dalam Perspektif Al-Qur'an. IQ: Jurnal Pendidikan Islam. (3). 1.

Suryawati, Dewi Prasari. (2016). Implementasi Pembelajaran Akidah Akhlak Terhadap Pembentukan Karakter Siswa di MTs Negeri Semanu Gunung Kidul. Jurnal Pendidikan Madrosah. (1). 2.

Sutriyani. (2013). Strategi Peningkatan Kompetensi Kecerdasan Spiritual dan Perilaku Keagamaan Siswa di MAN 2 Kota Cirebon. Tesis.

Sutriyono, Eko. Sistem Full Day School Untuk Penguatan Karakter Robbani di SMPIT Ash Sohwah Tanjung Redeb Berau. Tesis.

Suwatno, A. Sobandi, Rasto. (2012). Implementasi Proses Pembelajaran Dalam Mencapai Kompetensi Guru Bidang Keahlian Manajemen Perkantoran. Manajerial. (10). 20.

Suyitno. (2018). Metode Penelitian Kualitatif, Konsep, Prinsip, dan Operasionalnya. Tulung Agung: Akademi Pustaka.

Tanrere, Syamsul Bahri Otong Surasman, Ahmad Mubarok. (2020). Pengaruh Pengetahuan Keagamaan dan Kecerdasan Emosional Terhadap Perilaku Sosial Anak di SDIT Nur El Qosam Serang Banten. Alim: Journal of Islamic Education. (2). 1.

Taubah, Mufatihatut. (2015). Pendidikan Anak Dalam Keluarga Perspektif Islam. Jurnal Pendidikan Agama Islam. (3). 1.

Tim Pengembang Ilmu Pendidikan FIP-UPI. (2007). Ilmu dan Aplikasi Pendidikan. Bandung: Imperial Bhakti Utama.

Wahbah Mushthofa Az Zuhaili, Tafsir Al Munir fii Al 'Aqidah Wa Al Syari’ah Wa Al Minhaj, (Damaskus, Dar Al Fikr Al Ma'aashir 1418 H), Jld. 6, 245. 
Nasrulloh

Wardani, Novia Wahyu Margi Wahono. Keteladanan Guru Sebagai Proses Penguat.

Wibowo, Imam Suwardi dan Ririn Farnisa. (2018). Hubungan Peran Guru Dalam Proses Pembelajaran Terhadap Prestasi Belajar Siswa. Jurnal Gentala Pendidikan Dasar. (3). 2.

Wijaya, Hengki. (2020). Ringkasan dan Ulasan Buku Analisis Data Penelitian Kualitatif (Prof. Burhan

Bungin),

file://C:/Users/ASUS/AppData/Local/Temp/RingkasandanUlasanBukuAnalisisDataP enelitianKualitatifBurhanBungin.pdf, diakses pada tanggal 16 Oktober 2020.

Yasri, Muhammad. (2003). Ma'aalim fi-Ushul ad-Da'wah. Riyadh: Maktabah Malik Fahd.

Yaumi, Muhammad. (2013). Prinsip-Prinsip Pembelajaran Disesuaikan dengan Kurikulum 2013. Jakarta: PT. Kharisma Putra Utama.

Yusuf, Mukhammad. (2018). Hidup Sukses Dengan Tahajud. Yogyakarta: Kaktus.

Zamili, Moh. Menghindar Dari Bias: Praktik Triangulasi dan Kesahihan Riset Kualitatif. Article Research Gate. 